\title{
Comparison of post-tonsillectomy pain by using tramadol, lignocaine with adrenaline and normal saline swab in tonsillar fossae.
}

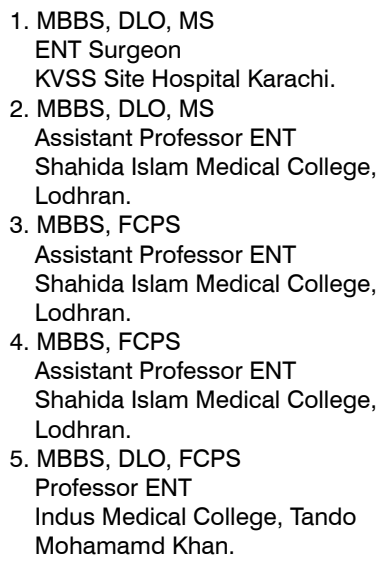

Correspondence Address: Dr. Tahir Hussain Khan

A-1/41, Rizwan Co-operative Housing Society, Scheme-33, University Road, Karachi. tahirhussainkhan99@gmail.com

Article received on: 24/05/2021

Accepted for publication: 20/07/2021

\begin{abstract}
Tahir Hussain Khan ${ }^{1}$, Ashfaq Hussain Rana ${ }^{2}$, Mohammad Afzal ${ }^{3}$, Farooq Bhutta ${ }^{4}$, Sohail A Malik
\end{abstract}
ABSTRACT... Objective: To compare the effects of pain by using tramadol, lignocaine $2 \%$ with adrenaline and normal saline (placebo) after tonsillectomy. Study Design: Randomized Controls Trial. Setting: Department of ENT, Social Security Landhi Hospital Karachi. Period: March 2019 to October 2019. Sampling Technique: Non probability. Material \& Methods: One hundred and twenty (120) patients with ASA-I status, age between 12 to 22 years were included randomly for this study. Divided the patients into three groups, group-1(L), group$2(\mathrm{~T})$ and group-3(S) and forty (40) patients were in each group. In group-1(L), Lignocaine $2 \%$ with adrenaline used. In group-2 (T), Tramadol used and in group-3 (S), normal saline swab (placebo) used in tonsillar fossae at the end of tonsillectomies. Pain assessment done after 30 minutes in PACU and every one hourly for 6 hours post operatively in ward. If recorded VAS for pain was more than 5 analgesic injection given in ward for pain control. Result: The result of our research revealed that there were no significant differences in the mean ages of the patients, weight of patients, sex distribution and the duration of surgeries among the all three groups. Post-operative pain score were significantly higher in (S) group than in the other two groups $(p<0.05)$. In Group-1(L) and Group-2 (T) pain score had non-significant $(p>0.05)$. Duration of first analgesic demand was longer in Group-L and in Group-T versus normal saline (Group-S), it was $134 \pm 18$ minutes in Group-L and in Group -T, it was $135 \pm 15$ minutes while in Group-S, it was $34 \pm 11$ minutes and $p<0.01$ significant. Conclusion: Uses of lignocaine $2 \%$ with adrenaline swab and Tramadol swab are better choice in tonsillar fossae at the end of tonsillectomies for post-operative pain control versus normal saline (placebo) swab.

Key words: $\quad$ Postoperative Pain, PACU, Tonsillectomy, Tonsillar Fossae.

Article Citation: Khan TH, Rana AH, Afzal M, Bhutta F, Malik SA. Comparison of posttonsillectomy pain by using tramadol, lignocaine with adrenaline and normal saline swab in tonsillar fossae. Professional Med J 2021; 28(8):1206-1210. https://doi.org/10.29309/TPMJ/2021.28.08.6606

\section{INTRODUCTION}

Tonsillectomy is the one of the common surgery dealt by otolaryngologist and it is most frequently performed. Although new different advancement in surgical and aesthetics technique came but difficulty of swallowing and severity of pain encountered. Pain after tonsillectomy is a concern which should be solved. ${ }^{1}$

Adenoidectomy and tonsillectomy are two common surgeries in ear nose and throat field. Postoperative pain is major concern and occurrs due to stimulation of nerve ending in tonsillar bed and throat muscle spasm. Usually these procedures are performed in pediatric age group. ${ }^{2}$

Pain control after tonsillectomy is remains challenging and controversial. Children are at more risk with use of opioid due to obstructive sleep apnea syndrome (OSAS) and posttonsillectomy hemorrhage with intake of antiinflammatory drug (NSAIDs). ${ }^{3}$

Tonsils are two egg and oval shaped lymphoid tissue in the oropharynx (postero-lateral compartment) between anterior and posterior pillars in a space called tonsillar sinus. Tonsils are part of lymphatic system and it is composed of $\mathrm{B}$ and $\mathrm{T}$ cells. Due to repeated viral and bacterial infection it may be hypertrophied. ${ }^{4}$

Post-operative pain control is essential part of treatment after tonsillectomy for reducing morbidity. Peaks of pain occur immediately after 
surgical procedure and remain for initial few days and can be manage by analgesia. ${ }^{5}$

Nociceptive-c fibers are located in peri-tonsillar space and responsible for post tonsillectomy pain. ${ }^{6}$

Some surgeon perform tonsillectomy as a day procedure. For encouragment of oral intake for maintenance of hydration and to minimize cry (pain), effective post-operative analgesia is required. Paracetamol and NSAIDs are frequently used for pain controls after tonsillectomy but its analgesic effects is not adequate. Use of NSAIDs are controversial and may cause post-operative hemorrhage (bleeding). Opioid provide effective analgesia but produce sedation and emesis. ${ }^{7}$

Bupivacaine has proven to be a potent analgesic and produces rapid response by sustained analgesic effect. ${ }^{8}$

Most common post-operative morbidity after tonsillectomy is a postoperative pain. ${ }^{9}$

Patients who are undergoing surgical intervention are afraid of post-operative pain and it is a greatest concern. All types of surgical interventions are associated with different levels of post-operative pain. ${ }^{10}$

\section{MATERIAL \& METHODS}

This randomized controlled trial was done at ENT Department, Social Security, Landhi Hospital Karachi from March 2019 to October 2019. Ethical approval was given by institutional ethical committee (SS/LH/ADMN/2020-21/2277). One hundred and twenty (120) patients with ASA-I status, age between 12 to 22 years male and female gender were included randomly for this study. The patients who had hepato-renal diseases, history of drug/alcohol abuse and patients who had been taking prolong analgesic/ opioid were excluded from this study. The patients were divided into three groups, 1-Group-L, 2-Group-T and 3-Group-S and forty patients were in each group. In Group-L, Lignocaine 2\% with adrenaline swab used in tonsillar fossa for 5 minutes at the end of tonsillectomy. In Group-T,
Tramadol swab used for 5 minutes at the end of tonsillectomy and in Group-S, normal saline swab (placebo) used for 5 minutes in tonsillar fossae at the end of tonsillectomies. VAS visual analog scale for pain set (0 to 10) $0=$ no pain to $10=$ severe pain. Pain assessment done after 30 minutes in recovery room and one hourly for 6 hours post operatively in ward. If recorded VAS was more than 5 , analgesic injection given and mean time for first requirement of analgesic noted. Data was analyzed by using software SPSS version 20. Mean, standard deviation (SD) noted, Annona and t-test applied. $\mathrm{P}<0.05$ was accepted as statistically significant.

\section{RESULTS}

No significant differences were found in the mean age, sex distribution and ASA physical status and duration of surgery among the three groups (Table-I). Post-operative pain score were significantly higher in the saline group (Group-S) than in the other two groups $(p<0.05)$ Group-L and Group-T had comparable pain score that were statistically non-significant $(p>0.05)$. Time for first analgesic requirement was longer in the Group- $\mathrm{L}$ and Group-T versus Group-S as it was $134 \pm 18$ minutes for Group-L, 135+12 minutes for Group-T, while in the Group-S, it was $34 \pm 11$ minutes. P value was $<0.01$. Analgesic consumption during the first 6 hours was almost equivalent for the Group-L and Group-T as 5 patients in Group-T and 7 patients in Group-L received one dose of analgesic. Mean consumption of analgesic $35 \pm 11 \mathrm{mg}, 33 \pm 15 \mathrm{mg}$ respectively in tramadol group and in lignocaine group which were nonsignificant $p>0.05$. Analgesic consumption was greater in saline group (Group-S) $75 \pm 14 \mathrm{mg}$. P value was $p<0.01$.

\section{DISCUSSION}

In a study it was reported that there were no significant difference between groups in terms of age and genders. ${ }^{11}$ Our study is also correlating with this study in which no difference were noted. A study revealed that there were no differences noted between the groups in relation to pain scores, analgesic requirement or first oral analgesic intake ${ }^{12}$ but in our study difference noted in pain score as well as analgesic requirement. 


\begin{tabular}{|l|c|c|c|}
\hline \multicolumn{1}{|c|}{ Parameters } & $\begin{array}{c}\text { Group-1 (L) } \\
\text { Lignocaine with } \\
\text { Adrenaline (n=40) }\end{array}$ & $\begin{array}{c}\text { Group-2 (T) } \\
\text { Tramadol } \\
\text { (n=40) }\end{array}$ & $\begin{array}{c}\text { Group-3 (S) } \\
\text { Normal Saline } \\
(\mathbf{n = 4 0 )}\end{array}$ \\
\hline Age in (years) & $14.9 \pm 2.5$ & $15.3 \pm 2.2$ & $15.2 \pm 2.3$ \\
\hline Weight in (Kg.) & $37.3 \pm 3.2$ & $38.2 \pm 3.1$ & $38.1 \pm 3.1$ \\
\hline ASA-I/ASA-II & $40 / 0$ & $40 / 0$ & $40 / 0$ \\
\hline Male/Female & $21 / 19$ & $22 / 18$ & $24 / 16$ \\
\hline Duration of surgery in (minutes) & $30 \pm 4$ & $27 \pm 9$ & $29 \pm 5$ \\
\hline
\end{tabular}

Table-I. Comparison of different parameters in Group-L, Group-T and in Group-S.

\begin{tabular}{|l|c|c|c|c|}
\hline \multicolumn{1}{|c|}{ Parameters } & $\begin{array}{c}\text { Group-1 (L) } \\
\mathbf{n = 4 0}\end{array}$ & $\begin{array}{c}\text { Grounp-2 (T) } \\
\mathbf{n = 4 0}\end{array}$ & $\begin{array}{c}\text { Group-3 (S) } \\
\mathbf{n = 4 0}\end{array}$ & P-Value \\
\hline Time for first analgesia in (mints) & $134 \pm 18$ & $135 \pm 12$ & $34 \pm 11$ & $<0.01$ \\
\hline Mean analgesic consumption in (mg) & $33 \pm 15$ & $35 \pm 11$ & $75 \pm 14$ & $<0.01$ \\
\hline
\end{tabular}

Table-II. Time for first analgesic demand and analgesic consumption in L, T and S groups.

\begin{tabular}{|l|c|c|c|}
\hline \multicolumn{1}{|c|}{ Parameters } & $\begin{array}{c}\text { Group-1 (L) } \\
\mathbf{n = 4 0}\end{array}$ & $\begin{array}{c}\text { Group-2 (T) } \\
\mathbf{n = 4 0}\end{array}$ & \multicolumn{1}{c|}{ P-Value } \\
\hline Time for $1^{\text {st }}$ analgesic demand & $134 \pm 18$ & $135 \pm 12$ & $>0.05$ (Non significant) \\
\hline Mean analgesic requirement in $(\mathrm{mg})$ & $33 \pm 15$ & $35 \pm 11$ & $>0.05$ (Non significant) \\
\hline
\end{tabular}

Table-III. Comparison of lignocaine with adrenaline group (L) and Tramadol group (T).

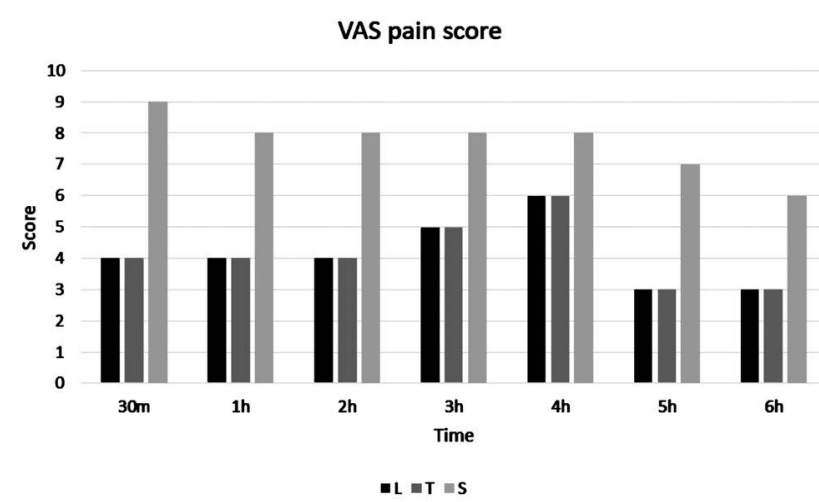

Figure-1. VAS pain score in group (L), group (T) and in group (S)

In a study it was mentioned that there were no significant difference among groups regarding time of first request for analgesia, analgesic consumption amount while in our study first request for analgesia is more in saline group as compared with lignocaine with adrenaline group and tramadol group. According to $\mathrm{Bk}$ et al pain was significantly lower in tramadol group ${ }^{13}$ our study is also co-relating with this study in which pain was also lower in tramadol group and in lignocaine with adrenaline group.
According to this study peri-tonsillar administration of tramadol was more effective for pain relief. ${ }^{14}$

In group B mean VAS score is $3.98 \pm 1$ and in group $\mathrm{M}$ it was $3.6 \pm 0.6$. $\mathrm{P}$ value is 0.005 statistically significant ${ }^{15}$ this is also co-relating with our study.

Duration of surgeries were similar between the groups, no statistical difference noted $p>0.05$. Pain score in group $I$ and group $P$ at recovery and at 2, 4, 8, 12 and 24 hours were lower than in group C. VAS Score in group I at first 2 hour postoperatively were significantly lower than in other two groups. ${ }^{16}$ This study is also co-relating our study.

\section{CONCLUSION}

Lignocaine with Adrenaline swab and Tramadol swab are better choices for post-operative pain control management versus normal Saline (placebo) swab in tonsillar fossae at the end of tonsillectomies.

Copyright@ 20 July, 2021. 


\section{REFERENCES}

1. Choubsaz M, Mohseni G, Ahmadi SJ, Sadeghi M. Comparison of the effects of adding of ketamine to preincisional bupivacaine injection on post operative pain relief after tonsillectomy in children. Journal of Reports in Pharmaceutical Sciences. 2017 Jan 1; 6(1):68-76.

2. El Daly A, Abd El Naby M, Emad P. Effect on postoperative pain after topical application of local anesthetics in the tonsillar fossa after tonsillectomy. The Egyptian Journal of Otolaryngology. 2019 Apr; 35(2):173-81.

3. Tan GX, Tunkel DE. Control of pain after tonsillectomy in children: A review. JAMA Otolaryngology-Head \& Neck Surgery. 2017 Sep 1; 143(9):937-42.

4. Maryam H, Amin J, Sedighe V, Vida A. Comparing the effects of peritonsillar infiltration of tramadol before and after the surgery on post-tonsillectomy pain. European Archives of Oto-Rhino-Laryngology. 2017 Jun $1 ; 274(6): 2521-7$.

5. Junaid M, Halim MS, Onali MA, Qadeer S, Khan HU, Ali NS. Intraoperative use of analgesics in tonsillar fossa and postoperative evaluation with visual analogue scale scores-a prospective, randomized, placebocontrolled, double-blind clinical trial. International archives of otorhinolaryngology. 2020 Mar; 24(1):e62-7.

6. de Sousa Caixeta JA, Sampaio JC, da Costa PS, Avelino MA. Analgesia for adenotonsillectomy in children: A comparison between peritonsillar infiltration of tramadol, ketamine, and placebo. European Archives of Oto-Rhino-Laryngology. 2020 Mar 10:1-8.

7. Teunkens A, Vermeulen K, Peters M, Fieuws S, Van de Velde $M$, Rex $S$. Bupivacaine infiltration in children for postoperative analgesia after tonsillectomy: A randomized controlled trial. European Journal of Anaesthesiology (EJA). 2019 Mar 1; 36(3):206-14.

8. Junaid M, Halim MS, Onali MA, Qadeer S, Khan HU, Ali NS. Intraoperative use of analgesics in tonsillar fossa and postoperative evaluation with visual analogue scale scores-a prospective, randomized, placebocontrolled, double-blind clinical trial. International archives of otorhinolaryngology. 2020 Mar; 24(1):e62-7.
9. El Daly A, Abd El Naby M, Emad P. Effect on postoperative pain after topical application of local anesthetics in the tonsillar fossa after tonsillectomy. The Egyptian Journal of Otolaryngology. 2019 Apr; 35(2):173-81.

10. Málek J, Ševčík P, Bejšovec D, Gabrhelík T, Hnilicová M, Křikava I, Mixa V. Postoperative pain management. Prague, Czech Republic: Mladá fronta. 2017:102-11.

11. Farzam H, Yari M, Mohammadi G, Rahmatinejad M. A comparative study of tramadol and lidocaine gel on complications of orotracheal intubation. Anaesthesia, Pain \& Intensive Care. 2020 Jun 24; 24(2):183-8.

12. de Sousa Caixeta JA, Sampaio JC, da Costa PS, Avelino MA. Analgesia for adenotonsillectomy in children: A comparison between peritonsillar infiltration of tramadol, ketamine, and placebo. European Archives of Oto-Rhino-Laryngology. 2020 Mar 10:1-8.

13. Akbay BK, Yildizbas S, Guclu E, Yilmaz S, Iskender A, Ozturk O. Analgesic efficacy of topical tramadol in the control of postoperative pain in children after tonsillectomy. Journal of anesthesia. 2010 Oct; 24(5):705-8.

14. Sarafraz M, Derakhshandeh V, Nesioonpour S, Araghi $S$. Efficacy of peritonsillar infiltration of ketamine, tramadol, and lidocaine for prevention of post tonsillectomy pain. Nigerian Journal of Medicine. 2016 Jun 13; 25(1):49-52.

15. Kumar KS, Danda VK. Comparative Clinical Study of $0.5 \%$ Hyperbaric Bupivacaine Alone and $0.5 \%$ Hyperbaric Bupivacaine with Midazolam Intrathecally for Lower Limb and Lower Abdominal Surgeries. Indian Journal of Anesthesia and Analgesia. 2018:505.

16. Ciftci B, Ekinci M, Celik EC, Kaciroglu A, Karakaya MA, Demiraran Y, Ozdenkaya Y. Comparison of intravenous ibuprofen and paracetamol for postoperative pain management after laparoscopic sleeve gastrectomy. A randomized controlled study. Obesity surgery. 2019 Mar; 29(3):765-70. 


\begin{tabular}{|c|c|c|c|}
\hline \multicolumn{4}{|c|}{ AUTHORSHIP AND CONTRIBUTION DECLARATION } \\
\hline Sr. \# & Author(s) Full Name & Contribution to the paper & Author(s) Signature \\
\hline 1 & Tahir Hussain Khan & $\begin{array}{l}\text { Designed the methodology } \\
\text { and wrote manuscript. }\end{array}$ & A \\
\hline 2 & Ashfaq Hussain Rana & $\begin{array}{l}\text { Helped in writing and } \\
\text { finalization. }\end{array}$ & As Rave \\
\hline 3 & Mohammad Afzal & Helped in data collection. & Panntta \\
\hline 4 & Farooq Bhutta & Helped in data analysis. & m. appal \\
\hline 5 & Sohail A Malik & $\begin{array}{l}\text { Supervised the study and } \\
\text { reviewed the article. }\end{array}$ & Soul \\
\hline
\end{tabular}

